\title{
Transnational Crime : Proses Sekuritisasi Pemerintah Indonesia terhadap ancaman perdagangan Narkotika
}

\author{
Restilia Polii \\ Universitas Sam Ratulangi \\ restiliapolii@gmail.com
}

\begin{abstract}
Abstrak
Tulisan ini akan membahas mengenai kejahatan lintas negara terutama perdagangan narkoba. Melalui literature review ini, penulis menggunakan berbagai referensi, yang didalamnya terdapat penjelasan mengenai perdagangan narkotika sebagai bagian dalam kejahatan lintas negara di dan bagaimana dampaknya bagi Indonesia. Kejahatan transnasional menimbulkan ancaman bagi negara, perekonomian negara dan masyarakat sipil. Aktor non negara dapat menggunakan kejahatan transnasional untuk mempromosikan tujuan politik mereka, kelompok ini mendapat kekuatan dari kemampuan mereka untuk menjalin hubungan lintas batas-batas negara. Di Indonesia sendiri, perdagangan narkotika menjadi isu yang terus berkembang dan terus mendapat perhatian pemerintah Indonesia.
\end{abstract}

Kata Kunci: Narkotika, transnational crime, perdagangan

\section{PENDAHULUAN}

Berakhirnya Perang Dingin yang ditandai dengan runtuhnya Tembok Berlin pada tahun 1989 telah memberikan perubahan yang signifikan terhadap sistem internasional. Seperti yang kita ketahui bahwa pada era Perang Dingin masalah internasional lebih bersifat tradisional atau militer, namun paradigma tersebut mengalami pergeseran pada pasca Perang Dingin menjadi ancaman-ancaman yang sifatnya non-militer. Ancaman -ancaman nonmiliter ini meliputi; masalah lingkungan hidup, migrasi , perdagangan manusia, perdagangan obat obatan terlarang, penyakit menular, dan masih banyak yang lainnya dengan ruang lingkup yang melewati batas-batas negara (transnational crime). Ancaman baru ini bersifat multidimensional yang apabila penanggulangannya kurang tepat maka ancaman yang diberikan bukan saja kepada negara tetapi juga pada tingkat individu. 
Berbicara tentang kejahatan transnasional, kawasan Asia Tenggara telah menjadi salah satu kawasan yang berpotensi dijadikan kawasan jaringan kejahatan internasional. Asia Tenggara merupakan salah satu kawasan yang tingkat kejahatan transnasionalnya relatif tinggi, khususnya drugs trafficking. Menurut Bambang Cipto, dalam bukunya Hubungan Internasional di Asia Tenggara (Teropong terhadap Dinamika, Realitas, dan Masa Depan) terbitan tahun 2007, khususnya dalam bab yang membahas mengenai Isu-isu keamanan non-tradisonal di Asia Tenggara pasca perang dingin memaparkan bahwa transnational crime berkembang pesat dengan memburuknya perekonomian ASEAN sebagai akibat dari krisis ekonomi sejak tahun 1998 yang menjadi salah satu alasan mengapa kejahatan semakin marak di kawasan Asia Tenggara. ${ }^{1}$

Dengan jumlah penduduk Asia Tenggara yang hampir 500 juta jiwa, menjadikan wilayah ini bukan saja sebagai produksi terbesar obat-obatan berbahaya, namun juga sebagai pasar yang cukup potensial bagi para produsen dan pengedar narkotika. Perdagangan narkotika ilegal tidak terlepas dari Asia Tenggara merupakan salah satu penghasil obatobatan terlarang terbesar didunia setelah "Bulan Sabit Emas" (Afganistan, India, Pakistan) dan Colombia. Sebutan "Segitiga Emas" atau The Golden Triangle yang merupakan daerah perbatasan Thailand, Myanmar dan Laos merupakan penghasil 60 persen produksi Opium dan Heroin di dunia. ${ }^{2}$ Jaringan Golden Triangle yang beroperasi di Myanmar, Burma, Thailand, Amerika Selatan dengan pusatnya Bangkok, Thailand, memiliki keterlibatan dengan kelompok jaringan internasional Golden Crescent yang beroperasi di Iran, Pakistan dan Afghanistan dengan pusatnya di Pakistan. ${ }^{3}$ Perdagangan narkotika tidak lepas dari peranan kelompok sindikat perdagangan narkotika internasional yang berperan sebagai drug dealer dalam menyelundupkan narkotika ke kawasan Asia Tenggara.

Karena itulah tepatnya pada tahun 1997 dibentuklah pertemuan para menteri pertahanan anggota ASEAN untuk menangani kejahatan lintas-negara ASEAN yang disebut Asean Ministerial Meeting on Transnational Crime (AMMTC), dan bertemu setiap 2 tahun

\footnotetext{
${ }^{1}$ Bambang Cipto, (2007), Hubungan Internasional di Asia Tenggara (Teropong terhadap dinamika, Kondisis riil dan Masa depan), Pustaka Pelajar, cetakan 1, hal. 225

${ }_{3}^{2}$ ASEAN Selayang Pandang. Diakses dari http://www.deplu.go.id/pdf.

3 Polisi tangkap dua anggota sindikat narkotika terdapat pada http://www.tempo.co.id/hg/jakarta/2002/03/30/brk,20020330-10,id.html
} 
sekali dalam menangani kejahatan lintas negara di kawasan Asia Tenggara ${ }^{4}$. Asean Ministerial Meeting on Transnational Crime ini merupakan badan pengambil keputusan tertinggi dalam kerjasama ASEAN memberantas kejahatan lintas batas (Transnational Crime/TC) dengan mekanisme pertemuan pejabat tingkat tinggi bidang kejahatan lintas negara (Senior Official Meeting on Transnational Crime/SOMTC) sebagai sub-ordinasinya. ${ }^{5}$ Pertemuan dibentuk sebagai upaya menangani kejahatan lintas batas yang mempengaruhi kawasan Asia Tenggara, seperti terorisme, perdagangan narkotika, penyelendupan senjata, pencucian uang, perdagangan manusia dan pembajakan, yang berpotensi untuk mengganggu perdamaian, kemakmuran dan kemajuan ASEAN. ${ }^{6}$ Dalam pertemuan-pertemuan tersebut kemudian disusunlah suatu rencana aksi ASEAN (Asean Plan of action to combat transnational crime). ${ }^{7}$

Di Indonesia sendiri, masalah narkotika saat ini sudah merupakan masalah yang serius karena menyangkut dengan generasi penerus bangsa. Bahkan pernah didapati salah satu oknum pejabat ditanah air, tertangkap tangan mengkonsumsi Narkotika. Jadi, dalam hal ini bukan hanya mengancam negara, tetapi juga hingga tingkat individu. Karena berdasarkan perkembangannya Indonesia bukan lagi sebagai konsumen melainkan juga sebagai produsen. Hal ini menyangkut seperti yang sudah dipaparkan sebelumnya karena adanya jaringan kejahatan transnasional khususnya perdagangan Narkotika yang melibatkan negaranegara di kawasan Asia Tenggara. Hal inilah yang menjadikan isu perdagangan narkotika menjadi hal yang menarik untuk dikaji sebagai kejahatan transnasional yang bisa saja mengancam keamanan negara. Khususnya dalam hal ini di Indonesia sendiri.

Berdasarkan latar belakang yang sudah dipaparkan diatas, maka dirumuskan pertanyaan penelitian Bagaimana proses sekuritisasi yang dilakukan oleh pemerintah Indonesia dalam menghadapi ancaman perdagangan Narkotika dari kawasan Asia Tenggara?

\footnotetext{
${ }^{4}$ Direktorat Jenderal Kerja Sama ASEAN Kementerian Luar Negeri Indonesia,( 2010), “Asean Selayang Pandang", (2010), Edisi ke-19, hal.48

${ }^{5}$ Ibid, hal.48-49

${ }^{6}$ Ibid, hal.49

${ }^{7}$ Ibid, hal.49
} 


\section{Kerangka Teori}

Sebagai alat analisa untuk menjawab pertanyaan penelitian, makalah ini akan menggunakan teori Sekuritisasi dari Barry Buzan. Terdapat beberapa konsep dari teori sekuritisasi ini yaitu: securitizing actor, speech act, existential threat, referent object, functional actor dan audience.

Menurut Barry Buzan, sekuritisasi melihat bahwa masalah keamanan merupakan hasil konstruksi. Artinya, suatu isu menjadi masalah keamanan karena adanya discourse content yang setidaknya memberikan pengaruh, ditambah lagi terdapat aktor-aktor yang mewacanakannya dengan mengatakan bahwa isu tersebut merupakan ancaman eksistensial bagi suatu entitas. ${ }^{8}$ Suatu isu menjadi masalah keamanan karena hasil promosi para aktor karena pengaruh konstruksi diskursif antar aktor dan audiens. Aktor mewacanakan dan audiens menyetujui. ${ }^{9}$ Konsep yang terdapat dalam sekuritisasi antara lain securitizing actors ialah aktor yang melakukan sekuritisasi, speech act ialah tindakan sang aktor dalam melakukan sekuritisasi, existensial threat ialah ancaman eksistensial yang diwacanakan oleh sang aktor yang akan muncul dari isu tersebut. Referent Object ialah entitas yang akan terancam jika isu tersebut tidak ditangani secara serius, Audience ialah pihak yang coba dipengaruhi oleh sang aktor agar mempercayai existensial threat, sedangkan functional actors ialah aktor yang secara signifikan sangat mempengaruhi dinamika perkembangan tersebut. $^{10}$

Securitizing actors (aktor-aktor sekuritisasi) adalah aktor-aktor yang melakukan sekuritisasi. Speech act adalah tindakan sang aktor dalam rangka melakukan sekuritisasi. Existential threat adalah ancaman eksistensial yang diwacanakan oleh sang aktor akan muncul dari isu tersebut. Referent object adalah entitas yang akan terancam dengan adanya isu tersebut jika tidak ditangangi secara serius. Audience adalah pihak-pihak yang coba dipengaruhi oleh sang aktor agar mempercayai adanya existential threat

\footnotetext{
${ }^{8}$ Barry Buzan, Ole Waever dan Jaap de Wilde, Security: A New Framework for Analysis, (London: Lynne Rienner Publishers, 1998), hal 24.

${ }^{9}$ Ibid, hal.25.

${ }^{10}$ Ibid, hal.26
} 
Dalam sekuritisasi isu perdagangan Narkotika di Indonesia ini securitizing actornya ialah pemerintahan Indonesia, speech act menggunakan Badan Narkotika Nasional (BNN) adalah sebuah Lembaga Pemerintah Non Kementerian (LPNK) Indonesia yang mempunyai tugas melaksanakan tugas pemerintahan di bidang pencegahan, pemberantasan penyalahgunaan dan peredaran gelap psikotropika, prekursor, dan bahan adiktif lainnya kecuali bahan adiktif untuk tembakau dan alkohol., refferent objectnya ialah NKRI sendiri. Audience merupakan seluruh elemen masyarakat Indonesia, sedangkan functional actor adalah pelaku perdagangan narkotika yang berada di wilayah Asia Tenggara dilihat dari variabel yang mendorongnya menjadi sebuah ancaman.

\section{PEMBAHASAN}

Kejahatan transnasional merupakan ancaman terhadap Negara dan masyarakat yang dapat mengikis human security. Perdagangan narkotika ilegal merupakan salah satu bentuk dari kejahatan transnasional, yang menyebabkan terjadinya permasalahan yang beRsifat multifaceted, seperti peningkatan penularan HIV/AIDS melalui pengguna narkotika jarum suntik, serta pencucian uang. Selain itu, kejahatan perdagangan manusia khususnya kejahatan yang terkait dengan ekspoitasi seksual sering dihubungkan dengan kejahatan perdagangan narkotika illegal.

Kejahatan perdagangan narkotika memiliki ciri-ciri: terorganisir (organized crime), berupa sindikat, dan terdapat suatu dukungan dana yang besar serta peredarannya memanfaatkan teknologi canggih. Modus peredaran gelap narkotika internasional selalu melibatkan warga negara asing dan berdampak terhadap teritorial dua negara atau lebih serta selalu didahului persiapan atau perencanaan yang dilakukan diluar batas teritorial negara tertentu. Semakin canggih teknologi telah dimanfaatkan oleh pelaku perdagangan narkotika ilegal untuk menyelundupkan narkotika illegal dari suatu negara ke negara lain seperti penggunaan kapal selam dan pesawat terbang. Adapun modus lain dari pengedar narkotika adalah menggunakan wanita sebagai kurir. Penggunaan wanita sebagai kurir narkotika dianggap sebagai cara aman dan tidak dicurigai oleh pihak keamanan suatu negara. Berkaitan dengan perdagangan narkotika ilegal ada tiga elemen penting didalamnya 
yaitu daerah yang menjadi pemasok, orang atau organisasi yang mendistribusikan narkotika serta pengguna atau pemakai narkotika.

Menurut WHO yang dimaksud dengan obat (drug) adalah setiap bahan (zat/substansi) yang jika masuk dalam organisme hidup akan memberikan perubahan pada satu atau lebih fungsi-fungsi organisme tersebut. Zat seperti opioda (morfin, heroin), kokain, ganja, sedative/hiprotika, dan alkohol merupakan zat yang mempunyai efek seperti itu, khususnya dalam fungsi berpikir, perasaan, dan perilaku orang yang memakainya. Penyalahgunaan zat dan substansi (drug abuse) adalah penggunaan zat yang bersangkutan tidak digunakan untuk keperluan pengobatan tetapi untuk menikmati efek yang ditimbulkan baik dalam dosis kecil maupun besar. Penyalahgunaan tersebut dapat menyebabkan ketergantungan (drug dependence). ${ }^{11}$

Pada dasarnya sekuritisasi dipahami sebagai proses politik untuk menjadikan suatu masalah/ isu yang tadinya bukan masalah/isu militer menjadi masalah keamanan, dengan melihat isu/masalah tersebut dari sisi security, sehingga kemudian menjadi isu/masalah tersebut dijadikan agenda nasional suatu negara. Konsep sekuritisasi sendiri merupakan konsep baru yang berkaitan dengan power of idea, yang dipahami sebagai kemampuan untuk memproduksi ide dan menghasilkan sebuah discourse untuk mempengaruhi pihak lain. Unsur political process dalam tahapan sekuritisasi menunjukan besarnya peran negara. Isu awalnya bukanlah prioritas negara kemudian beranjak menjadi masalah keamanan nasional, di mana negara berhak untuk sepenuhnya concern dalam isu tersebut.

Di Indonesia sendiri, penanggulangan terhadap bahaya narkotika sudah ada sejak tahun 1971. Hal ini ditandai dengan dikeluarkannya Instruksi Presiden Republik Indonesia (Inpres) Nomor 6 Tahun 1971 kepada Kepala Badan Koordinasi Intelijen Nasional (BAKIN) untuk menanggulangi 6 (enam) permasalahan nasional yang menonjol, yaitu pemberantasan uang palsu, penanggulangan penyalahgunaan narkoba, penanggulangan penyelundupan, penanggulangan kenakalan remaja, penanggulangan subversi, pengawasan orang asing.

Berdasarkan Inpres tersebut Kepala BAKIN membentuk Bakolak Inpres Tahun 1971 yang salah satu tugas dan fungsinya adalah menanggulangi bahaya narkoba. Bakolak Inpres

\footnotetext{
${ }^{11}$ Dadang Hawari, 1991. Penyalahgunaan Narkotika dan Zat Adiktif. Jakarta: BPFKUL, hal.15
} 
adalah sebuah badan koordinasi kecil yang beranggotakan wakil-wakil dari Departemen Kesehatan, Departemen Sosial, Departemen Luar Negeri, Kejaksaan Agung, dan lain-lain, yang berada di bawah komando dan bertanggung jawab kepada Kepala BAKIN. Tetapi Badan ini tidak mempunyai wewenang operasional dan tidak mendapat alokasi anggaran sendiri dari ABPN melainkan disediakan berdasarkan kebijakan internal BAKIN.

Pada masa itu, permasalahan narkoba di Indonesia masih merupakan permasalahan kecil dan Pemerintah Orde Baru terus memandang dan berkeyakinan bahwa permasalahan narkoba di Indonesia tidak akan berkembang karena bangsa Indonesia adalah bangsa yang ber-Pancasila dan religius. Pandangan ini ternyata membuat pemerintah dan seluruh bangsa Indonesia lengah terhadap ancaman bahaya narkoba, sehingga pada saat permasalahan narkoba meledak dengan dibarengi krisis mata uang regional pada pertengahan tahun 1997, pemerintah dan bangsa Indonesia seakan tidak siap untuk menghadapinya, berbeda dengan Singapura, Malaysia dan Thailand yang sejak tahun 1970 secara konsisten dan terus menerus memerangi bahaya narkoba.

Menghadapi permasalahan narkoba yang berkecenderungan terus meningkat, Pemerintah dan Dewan Perwakilan Rakyat Republik Indonesia (DPR-RI) mengesahkan Undang-Undang Nomor 5 Tahun 1997 tentang Psikotropika dan Undang-Undang Nomor 22 Tahun 1997 tentang Narkotika. Berdasarkan kedua Undang-undang tersebut, Pemerintah yang saat itu adalah Presiden Abdurahman Wahid membentuk Badan Koordinasi Narkotika Nasional (BKNN), dengan Keputusan Presiden Nomor 116 Tahun 1999. BKNN adalah suatu Badan Koordinasi penanggulangan narkoba yang beranggotakan 25 Instansi Pemerintah terkait.

Dalam perkembangannya BKNN sebagai badan koordinasi dirasakan tidak memadai lagi untuk menghadapi ancaman bahaya narkoba yang makin serius. Oleh karenanya berdasarkan Keputusan Presiden Nomor 17 Tahun 2002 tentang Badan Narkotika Nasional, BKNN diganti dengan Badan Narkotika Nasional (BNN). BNN, sebagai sebuah lembaga forum dengan tugas mengoordinasikan 25 instansi pemerintah terkait dan ditambah dengan kewenangan operasional, mempunyai tugas dan fungsi: 
1. Mengoordinasikan instansi pemerintah terkait dalam perumusan dan pelaksanaan kebijakan nasional penanggulangan narkoba; dan

2. Mengkoordinasikan pelaksanaan kebijakan nasional penanggulangan narkoba.

Mulai tahun 2003 BNN baru mendapatkan alokasi anggaran dari APBN. Dengan alokasi anggaran APBN tersebut, BNN terus berupaya meningkatkan kinerjanya bersamasama dengan BNP dan BNK. Namun karena tanpa struktur kelembagaan yang memilki jalur komando yang tegas dan hanya bersifat koordinatif (kesamaan fungsional semata), maka BNN dinilai tidak dapat bekerja optimal dan tidak akan mampu menghadapi permasalahan narkoba yang terus meningkat dan makin serius. Oleh karena itu pemegang otoritas dalam hal ini segera menerbitkan Peraturan Presiden Nomor 83 Tahun 2007 tentang Badan Narkotika Nasional, Badan Narkotika Propinsi (BNP) dan Badan Narkotika Kabupaten/Kota (BNK), yang memiliki kewenangan operasional melalui kewenangan Anggota BNN terkait dalam satuan tugas, yang mana BNN-BNP-BNKab/Kota merupakan mitra kerja pada tingkat nasional, propinsi dan kabupaten/kota yang masing-masing bertanggung jawab kepada Presiden, Gubernur dan Bupati/Walikota, dan yang masing-masing (BNP dan BN Kab/Kota) tidak mempunyai hubungan struktural-vertikal dengan BNN.

Merespon perkembangan permasalahan narkoba yang terus meningkat dan makin serius, maka Ketetapan MPR-RI Nomor VI/MPR/2002 melalui Sidang Umum Majelis Permusyawaratan Rakyat Republik Indonesia (MPR-RI) Tahun 2002 telah merekomendasikan kepada DPR-RI dan Presiden RI untuk melakukan perubahan atas Undang-Undang Nomor 22 Tahun 1997 tentang Narkotika. Oleh karena itu, Pemerintah dan DPR-RI mengesahkan dan mengundangkan Undang-Undang Nomor 35 Tahun 2009 tentang Narkotika, sebagai perubahan atas UU Nomor 22 Tahun 1997. Berdasarkan UU Nomor 35 Tahun 2009 tersebut, BNN diberikan kewenangan penyelidikan dan penyidikan tindak pidana narkotika dan prekursor narkotika. Jadi yang diperjuangkan BNN saat ini adalah cara untuk mengatasi para bandar atau pengedar narkoba, karena disinyalir dan terbukti pada beberapa kasus penjualan narkoba sudah digunakan untuk pendanaan teroris (Narco Terrorism) dan juga untuk menghindari kegiatan penjualan narkoba untuk biaya politik (Narco for Politic). 
Jika dinalisa dengan menggunakan teori sekuritisasi dari Buzan, Dalam sekuritisasi isu perdagangan Narkotika di Indonesia ini securitizing actornya ialah pemerintahan Indonesia, speech act menggunakan Badan Narkotika Nasional (BNN) adalah sebuah Lembaga Pemerintah Non Kementerian (LPNK) Indonesia yang mempunyai tugas melaksanakan tugas pemerintahan di bidang pencegahan, pemberantasan penyalahgunaan dan peredaran gelap psikotropika, prekursor, dan bahan adiktif lainnya kecuali bahan adiktif untuk tembakau dan alkohol. Refferent objectnya ialah NKRI sendiri. Audience merupakan seluruh elemen masyarakat Indonesia, sedangkan functional actor adalah pelaku perdagangan narkotika yang berada di wilayah Asia Tenggara dilihat dari variabel yang mendorongnya menjadi sebuah ancaman.

Setelah dianalisa lebih jauh, isu perdagangan Narkotika ini bisa dikatakan masih dalam tahap proses sekuritisasi, karena sampai saat ini isu ini masih termasuk dalam tindakan pidana. Tetapi berdasarkan perkembangannya, isu perdagangan Narkotika memang sudah ditindak secara serius oleh pemerintah Indonesia sebagai ancaman. Buktinya dengan berbagai amandemen peraturan yang dilakukan untuk mengatasi masalah ini. Bahkan dengan adanya alokasi dana APBN dalam menindaklanjuti isu ini menjadi salah satu bukti bahwa pemerintah Indonesia merasa terancam dengan keberadaan perdagangan Narkotika ini.

\section{Kesimpulan}

Kejahatan transnasional di Asia Tenggara merupakan masalah yang penting dan perlu untuk dibahas dalam konteks ASEAN dan keamanan regional. Kejahatan transnasional menimbulkan ancaman bagi negara, perekonomian negara dan masyarakat sipil. Aktor non negara dapat menggunakan kejahatan transnasional untuk mempromosikan tujuan politik mereka, kelompok ini mendapat kekuatan dari kemampuan mereka untuk menjalin hubungan lintas batas-batas negara.

Di Indonesia sendiri, perdagangan narkotika menjadi isu yang tersu berkembang dan

terus ditindaklanjutioelh pemerintah Indonesia. Karena Perdagangan narkotika selalu merembes ke masalah-masalah keamanan lainnya misalnya HIV/AIDS, dan juga selalu 
terkait dengan pencucian uang yang merupakan salah satu kejahatan transnasional yang paling berbahaya. Kegiatan perdagangan narkotika merupakan tantangan terhadap kedaulatan nasional dan integritas negara serta mengancam kelangsungan pemerintahan yang sah. Selain itu, kejahatan pencucian uang hasil narkotika melemahkan kredibilitas lembaga keuangan dan mengganggu ketertiban sosial. Tetapi meskipun demikian, perdagangan narkotika di Indonesia sendiri masih ditangani dengan tindakan pidana. Jadi, pada akhirnya makalah ini mengasumsikan bahwa sekuritisasi isu perdagangan narkotika di Indonesia masih dalam proses.

\section{Daftar Pustaka}

Bambang Cipto, Hubungan Internasional di Asia Tenggara (Teropong terhadap dinamika, Kondisis riil dan Masa depan), 2007, Yogyakarta: Pustaka Pelajar

Barry Buzan, Ole Waever dan Jaap de Wilde, Security: A New Framework for Analysis, 1998, London: Lynne Rienner Publishers

Direktorat Jenderal Kerja Sama ASEAN Kementerian Luar Negeri Indonesia, "Asean Selayang Pandang", 2010, Jakarta

Dadang Hawari, 1991. Penyalahgunaan Narkotika dan Zat Adiktif. Jakarta: BPFKUL http://www.deplu.go.id/pdf.

http://www.tempo.co.id/hg/jakarta/2002/03/30/brk,20020330-10,id.html 